\title{
A child's development of interactional competence in a Swedish L2 classroom
}

Asta Cekaite Thunqvist

Linköping University Post Print

N.B.: When citing this work, cite the original article.

This is the authors' version of the following article:

Asta Cekaite Thunqvist, A child's development of interactional competence in a Swedish L2 classroom, 2007, The Modern language journal, (91), 1, 45-62.

which has been published in final form at:

http://dx.doi.org/10.1111/j.1540-4781.2007.00509.x

Copyright: Wiley-Blackwell

http://eu.wiley.com/WileyCDA/Brand/id-35.html

Postprint available at: Linköping University Electronic Press

http://urn.kb.se/resolve?urn=urn:nbn:se:liu:diva-39020 


\section{Developing interactional competence in a Swedish $\mathbf{L 2}$ classroom \\ Asta Cekaite, Department of Child Studies, Linköping University}

Published as: Cekaite, A. (2007). A child's development of interactional competence in a Swedish L2 classroom. The Modern Language Journal, 91, 45-62.

The present study explores a child L2 novice's emergent interactional competence during her first year in a Swedish immersion classroom. Within the theoretical framework of situated learning it focuses on how the novice acquires expertise in a specific classroom practice: multiparty classroom talk. The data cover three periods (the early, mid-, and late phase) of her first school year. The methods adopted combine a microanalytic approach with ethnographic fieldwork analyses of L2 socialization within a classroom community.

The analyses revealed systematic changes in the novice's interactional engagements. An interplay of language skills and turn-taking skills influenced her participation in multiparty talk during the three periods, casting her as (i) a silent child, (ii) a noisy and loud child, and as (iii) a skilful student. These changes indicate that learning cannot be seen as a unilinear development of a single learner identity. It is argued that a detailed longitudinal analysis may provide important insights into the relation between participation and L2 learning. Instead of unilinear development of a single 'learner' identity we may find different participation patterns linked to distinct language learning affordances over time.

Key words: interactional competence, children's L2 learning, language competence, turn-taking, learner identity.

Schooling is a significant part of children's everyday life, and socialization into the interactional management of classroom talk (e.g., turn design in a competitive multiparty classroom setting) 
constitutes an essential part of children's 'learning lessons', their ways of becoming competent members of a classroom community (Mehan, 1979). ${ }^{1}$ As demonstrated by second language (L2) ethnographies, participation in social activities in the classroom is related to second language acquisition and socialization (e.g., Bayley \& Schecter, 2003; Duff, 1995; Hall 1998; Morita, 2000; Willet, 1995). L2 learning, therefore, needs to be studied in relation to the novice's interactional management of classroom activities.

The present ethnographically oriented study tracks an L2 novice's participation in an immersion classroom. Using a longitudinal design, it explores a 7-year-old Kurdish girl's emergent interactional competence during her first year in a language classroom. Interactional competence involves a range of skills for using language to accomplish social actions, including social aspects of language use such as knowing when, how, and with whom to engage in conversational activities (Hymes, 1972; Schegloff et al., 2002). In the present study it is defined as participants' knowledge of the interactional architecture of a specific discursive practice, including knowing how to configure a range of resources through which this practice is created (Young \& Miller, 2004, p. 520; Hall, 1999). It entails knowledge of linguistic resources constituting particular activities (the lexis and syntactic structures) (Young \& Miller, 2004), pragmatic skills, such as topic introduction and maintenance (Blum-Kulka, 1997), turn-taking and sequential organization of talk (Ford \& Thompson, 1996; Markee, 2000), and the communicative roles associated with the practice (Ochs, 1996).

In a dialogic sense, then, participation and the accomplishment of social action in particular communities of practice are dependent upon a realm of tacit interactional competencies associated with recurrent social activities. The present study focuses on how a child novice acquires expertise in a specific classroom practice: multiparty classroom talk. A detailed 
longitudinal case study of an L2 speaker's socialization to the interactional management of classroom multiparty talk can afford important insights into the ways in which interactional competencies are deployed and developed in situated interactions. One of the keys to understanding L2 learning and novices' emergent interactional skills involves attending to learners' management of the turn-taking system and to the allocation of turns within specific discursive practices (Hall, 1998; Mondada \& Pekarek Doehler, 2004; Young \& Miller, 2004). ${ }^{2}$ Specifically, we will focus on resources the child novice employed when self-selecting in teacher-led multiparty conversational activities and on the interplay between emergent language skills and turn-taking skills.

The present study draws on the theory of legitimate peripheral participation (Lave \& Wenger, 1991), which argues that learning is evident in novices' changing participant status and their move from peripheral to increasingly active participation in a given activity. Learning is linked to assistance and scaffolding by more experienced participants (Vygotskij, 1978) and participant observation (Ohta, 1999; Rogoff, 2003) manifested through different forms of peripheral participation. Peripheral participation has been shown to be a key part of socialization to a given community, including educational settings (Ohta, 1999, p. 1496). In line with the theory of situated learning, one of the major educational tenets is the 'situatedness of school', which implies that learning can never be considered as "culturally "free standing", (Bruner, 1996, p. 28). Thus, central to our understanding of classroom learning is to focus on how novices negotiate access to a variety of classroom activities, what skills and competencies are cultivated and recognized as valued. 
Studies on children's socialization in L2 educational settings have primarily explored the teacher's role in socialization processes and organization of classroom practices (for a detailed review, see Watson-Gegeo, 2004). As demonstrated by He (2000) in her language socialization study of Chinese language heritage classrooms for children (4-8 years), participation in educational setting involves not only socialization to the cultural norms of the target culture, but also socialization into the interactional norms and practices appropriate to a specific classroom activity. He (2003) criticizes the idea of L2 learners as being a homogenous group, and examines the interactional processes through which learners in classroom interactions adopt or are positioned into varied speech roles within classroom interactions. In an ethnographical study of individual L2 learners in an English elementary classroom, Toohey (1998) similarly demonstrated, how the teacher's notions of learning (and language learners' abilities) led to constructions of a positive or problematic learner identity for each child, which in turn shaped the learning affordances the teacher made available to each child (cf., Hawkins, 2005).

Until now, relatively few classroom studies have considered the genesis of child novices' L2 interactional competence over time, including detailed mappings of language and pragmatic interactional resources (but see Pallotti, 2001; Willet, 1995). Such a focus entails close examination of the varied ways in which individual learners participate and are positioned in communicative practices, and how these processes influence novices' interactional repertoires (e.g. Schieffelin \& Ochs, 1996; Watson-Gegeo, 2004). . $^{3}$

In a language socialization study of novice L2 learners during one year in an American elementary classroom, Willet (1995) explored how three girls appropriated and elaborated the interactional routine of phonics seatwork and were able to create a peer 'learning community' 
that facilitated their L2 acquisition. As their L2 competence grew, earlier forms of formulaic language associated with the particular activity were employed in a syntactically new manner, allowing for more language play and restructuring of language and interactional resources.

A L2 novice's participation in informal multiparty conversations has been examined in a study of a 5-year-old Moroccan girl's first year in an Italian pre-school (Pallotti, 2001). When joining multiparty encounters, she relied extensively on external appropriations, that is, repetition of utterances, addressed to someone else. Such devices allowed her to produce topically relevant contributions while her linguistic skills were still limited.

In a longitudinal study of children's socialization of interactional skills in a Japanese immersion classroom, Kanagy (1999) has demonstrated how the teacher carefully staged performance of scripted, that is, fairly predictable classroom events (interactional routines of taking attendance, greeting and leave-taking), thereby scaffolding children's individual performances. Hence, classroom routines with a scripted, fairly predictable interactional organization enabled and supported the L2 novice's participation in learning activities from early on.

Similarly, research on school-age children's (7-16 years) acquisition of L2 pragmatics has suggested that L2 novices are able to accomplish pragmatic actions (requests) in L2 in a socially appropriate, polite manner, even if their grammar skills are very limited (Ellis, 1992; Walters, 1980). According to the two-dimensional pragmatic model (Bialystok, 1993), children need to initially acquire analytic representations of pragmatic knowledge, and more or less fully develop them at school age, whereas adults may rely on universal pragmatic knowledge, acquired through participation in a variety of communities of practice (for more on the universal pragmatic mode, 
see Kasper \& Rose, 2002). Presently, I would like to argue for the need for a detailed study of the situated interplay between language and pragmatic competencies, as they are displayed and coconstructed in children's L2 interactions.

\section{Interactional organization of classroom multiparty conversational activities}

Recurrent communicative events based on the predictable patterning of language use constitute an important locus for language socialization and learning, both in L1 and L2 settings (Kanagy, 1999; Peters \& Boggs, 1986; Willet, 1995). Educational settings also involve less scripted albeit recurrent conversational activities, e.g. multiparty conversations.

As demonstrated by Tsui and Garcia's (2000) longitudinal study of two Chinese novices' participation in whole-group activities in a US multilingual preschool, such activities present a challenge for L2 novices, as their participation may be severely curtailed by their limited L2 skills (e.g., Platt \& Troudi, 1997). Whole-group conversational activities are organized around children's verbal contributions, and talk constitutes the primary means of participation. In language classrooms, such activities are intended to provide practice of conversational skills in L2 (e.g., Hall, 2004), and students' active participation is prompted through opportunities for self-selection. ${ }^{4}$ In his seminal work on first-graders' participation patterns in monolingual classrooms, Mehan (1979) demonstrated, that, in order for students' initiatives to be incorporated into multiparty instructional activities, the contribution had to be coherent and relevant to the conversation at hand. It also had to be interesting and original.

Also, for L2 novices, 'accessing the right thing to say, on-line, when it counts, as in the case of an ongoing conversation, is crucial' (Bardovi-Harlig \& Salsbury, 2004, p. 222). Participation in 
teacher-fronted activities involves not only the skills to produce linguistically elaborate contributions and to adequately interpret ongoing talk. Getting a turn at talk also requires that the student's recognize classroom turn-taking procedures, including rules for self-selection. While the projectability of talk (Sacks et al., 1974), including foreseeable grammatical and pragmatic features of turn composition, provides participants with resources to locate an upcoming place to begin speaking at a possible turn transition point (TRP) (Ford \& Thompson, 1996), the student also needs to employ a winning turn-design and to know how to bring his/her turn to completion (Snow \& Blum-Kulka, 2002).

Many of these skills must be acquired through implicit socialization, namely, through novices' repeated participation in multiparty classroom practices. By focusing on how novices' selfselections are introduced and organized, and how they are negotiated, accepted or rejected, we can get a glimpse of the sociocultural patterns and tacit norms that guide social interaction in a language classroom.

In the following, we will explore in detail Fusi's, -a L2 novice's - changing participation patterns during multiparty conversational activities in a Swedish immersion classroom. The study presented here adds to the literature on children's L2 socialization in educational settings. However, the primary focus is not on the teacher's organization of learning practices, but on the longitudinal microgenesis of the child's interactional competence in the classroom. By examining her self-selections over a year's time, we will investigate the emergent nature of interactional skills. Specifically, we will focus on the situated interplay of emergent language skills and turntaking skills, and how this, in turn, affects participation in classroom activities. 


\section{METHOD}

\section{Setting}

The data consist of video and audio recordings of everyday interactions in a Swedish immersion class for refugee and immigrant children in a so-called 'mottagningsklass' (literally: 'reception classroom') in a Swedish school. The present group included children in grades 1-3 (7 to 10 years). The class met five days a week, 4-6 hours a day. All children in this class of nine (four girls and five boys) were beginner learners, who had recently arrived in Sweden. However, the children's time spent in Sweden and in this class varied, and they differed in their L2 proficiency.

The children in the immersion class came from Iraq, the Kurdistan in Iraq, the Kurdish part of Turkey, Lebanon and Thailand. As their first language they spoke Thai (Nok), Kurdish (Fusi, Hiwa and Sawan), and Arabic (Abdi, Layla, Rana and Miran). Swedish was the lingua franca of schooling. The main teacher, Vera, was a native Swedish speaker. She was an experienced teacher, who had worked with children many years. A teacher's aid, Fare, (Swedish-Arabic bilingual), assisted Vera. The names of the teachers, as well as the names of all students, have been fictionalized to ensure anonymity.

The present case study concerns Fusi, 7-year old Kurdish girl from Iraq. She had no prior schooling experience, and was one of the youngest children in the group. Fusi was one of the latest arrivals in the class and an L2 novice with very limited skills in Swedish. She also mastered some Arabic, though her native language was Kurdish. The school was her primary source of contact with the Swedish society and language. Fusi came from a large family with many siblings 
and her elder sisters used to help her with school homework. When the recordings began, Fusi had spent about 2 months in Sweden at school.

\section{Classroom activities}

The teachers employed teaching techniques that were centred on active student participation. The activities ranged from teacher-led book reading or story-telling, sharing time and singing to individual work on tasks such as writing, mathematics or aesthetic activities (e.g., drawing). In order to maintain the children's home language as well to facilitate their participation in the L2 immersion, home language teachers worked with the children in the classroom at least once a week (translating the teacher's instructions and interacting with the children).

The teacher, Vera, organized classroom activities in order to create what she called 'språktillfällen' ('occasions for speaking Swedish') (cf., Hall's (2004) study on activities for 'practising speaking Spanish'). She was attentive to the children's initiatives, and focused her instructions and spontaneous whole-group talk on their topics of interest. The children recurrently contributed through spontaneous comments. Speakership was primarily distributed through students' self-selections. Such organization of communicative activities created a great deal of uncertainty as to who would speak when a turn terminated, resulting in turn-taking competitions and simultaneous talk. Moreover, the teacher's cooperation was needed to establish the students' self-selections as ratified contributions (Goffman, 1981).

Classroom life entailed, thus, a great deal of improvisation, and often deviated from what can be seen as an official pedagogic agenda. The teacher, Vera, and the teacher's aid, Fare, were greatly 
appreciated by the students. Importantly, the lenient atmosphere of the classroom did not evolve into chaotic behaviour. The students' classroom conduct was guided by a set of tacit (at times, explicitly articulated) norms. For instance, the children needed to show respect to other students' verbal contributions. The teachers occasionally disciplined the students for too loud and competitive interactional behaviour by reminding them to 'think before speaking' and to listen to what others were saying.

\section{Recordings and data}

The children's classroom interactions as well as their play activities were video recorded during three periods, covering an early (autumn), mid- (winter) and late phase (late spring) of the school year (total of 90 hours of recordings). The main data for this study are recordings of teacher-led whole-group conversational activities, which have been transcribed by the author. The translations were done by a native speaker of English, and our ambition has been to preserve the children's original style of speaking to the greatest extent possible, including errors (e.g., omitted verb copulas 'Jag åtta år', 'I eight years old'; 'jag klar alla' 'I done everything'). Recurring patterns of Fusi's interactional exchanges were found through detailed analysis of selected videotaped classroom activities. The conversations used in the present paper were selected to represent Fusi's emergent interactional skills.

\section{Methodological considerations}

Methodologically, the choice of longitudinal naturalistic data was inspired by studies within language socialization paradigms (cf., Garrett \& Baquedano-Lopez, 2002; Schieffelin \& Ochs, 1996). The analysis is also influenced by conversation analysis (cf., Heritage, 1984) and its detailed attention to 
interactional processes, explored through participants' sense-making orientations on a turn-by-turn basis.

Integrating microanalyses of data with an ethnographic approach allows us to more fully analyse the children's interactional contributions, which in many cases were comprehensible only in the light of the shared interactional biography of the classroom community and the classroom-specific interactional arrangements (Peräkylä, 1995). All in all, longitudinal data collection, combined with a microanalytical approach, enables exploration of a novice's performances over time as well as documentation of the microgenesis of the novice's interactional competence, locating changes in a deeply contextualized account of interactional activities in the classroom (e.g., Kasper \& Rose, 2002; Schieffelin \& Ochs, 1996).

\section{THE FIRST PERIOD: DYADIC EXCHANGES}

In this section, I will briefly describe the ways in which Fusi participated in the everyday life of the classroom community at the outset of the school year, that is, during her first period in the immersion classroom. Fusi was generally silent and appeared to be uninterested during teacherfronted interactional activities, which were based on quick and competitive multiparty talk. Her active vocabulary included the Swedish numbers one ('ett') to ten ('tio') and words such as 'titta', 'här', 'hejdå', 'nej’ ('look', 'here', 'bye-bye', 'no'), recurrently combined in conventionalized phrases such as summonses, simple displays of disagreement, leave-taking and greeting routines. Knowing a handful of conventionalized phrases allowed her to join routine 
classroom activities (e.g., song and rhyme performances, greetings or asking for a hug from the teacher before leaving the classroom).

However, Fusi was mostly on her own, both in the classroom and on the playground, and she recurrently tried to get the teacher's and the children's attention by pretending to run away from the schoolyard, or by pretending to cry in the classroom (seated with her face in her hands). However, the peer group and the teachers became rather quickly bored with her staged escapes. Fusi complained to the teaching aid, Fare, that she did not want to live in Sweden, and she was quite unhappy.

\section{Drawing on the visual modality in summoning the teacher}

At the outset of the year, Fusi's verbal participation was limited to individual work-on-task (e.g., drawing, building, colouring 'cartoon' houses), where talk was only one of the means of participating (Goffman, 1963, p. 86). Together with nonverbal actions, Fusi deployed a limited set of basic interactional moves, such as summoning the teacher by name, or used directives (e.g., asking to look at a given classroom artefact).

In the following example, the children are working on individual drawing tasks, and the teacher, Vera, is standing at some distance from Fusi's desk.

Ex. 1. Teacher VERA, the girls Fusi, Nok, and the boys Hiwa, Sawan.

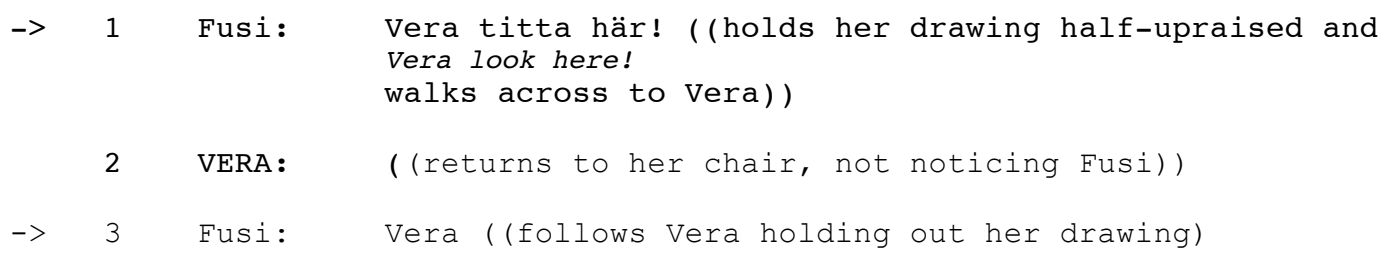




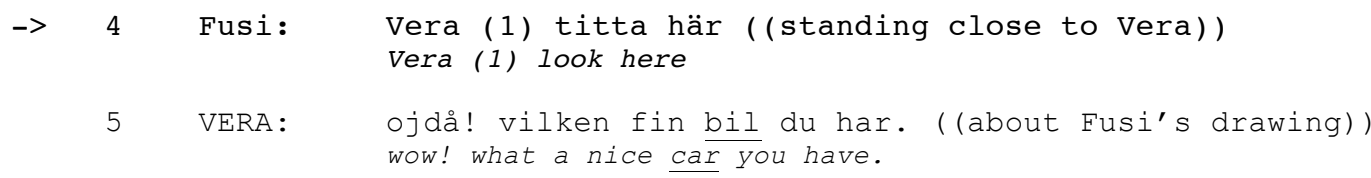

While summoning the teacher,Vera, to look at her drawing, Fusi shows it to her. She also leaves her desk, heading towards Vera, who does not respond. Instead she moves back to her place in front of the classroom (line 2), and Fusi follows after her (lines 3; 4). It is only when she has positioned herself close to the teacher that Fusi gets a response, in the form of a comment and a positive evaluation (line 5). Hence, meaning making is heavily embedded in a visual activity context: Fusi's display of a classroom artefact, the drawing, indicates the communicative content of her summons.

\section{Language choice: choosing an appropriate recipient}

As previously mentioned, even Fusi's understanding of rather simple issues of classroom life required extensive explanations and negotiations. Therefore, the teacher recurrently relied on the other Kurdish children and on the teacher's aid, Fare, to translate her instructions to Fusi. Fusi herself often employed Kurdish, as well as some basic Arabic.

The following episode (Ex. 2) involved such a use of Arabic on Fusi's part. Just some time before Vera had decided that the children needed to change their seating arrangements in the classroom. They had been moving their desks around the classroom, and after some commotion, the children were engaged in play formatted on the current classroom activity: when someone moved to another child's desk, s/he would laughingly claim the identity of that child (for instance, Nok: ‘jag Karwan'; 'I Karwan’). Usually, this play was greatly appreciated by the children. The key issue was to claim another person's identity by taking his/her place. Fusi reintroduced this play 
activity somewhat later, and she placed herself on Vera's chair and playfully addressed Ahmed, an Arab boy. At the time, some other children were seated on the floor in front of Vera's chair.

Ex. 2. The girls Fusi, Nok, and the boys Ahmed and Abdi.

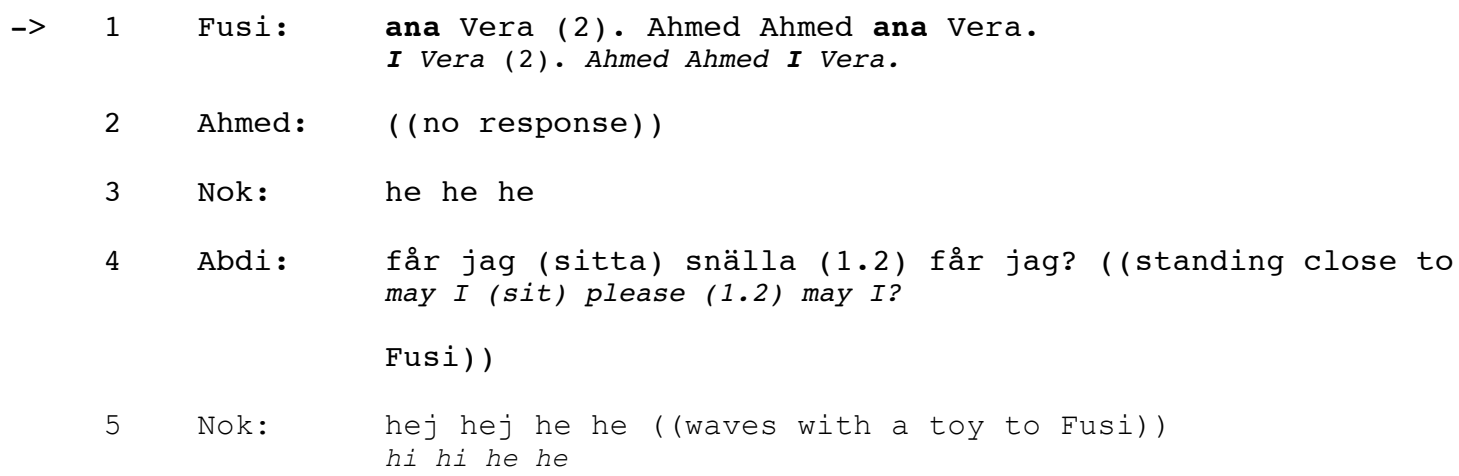

Fusi summonses Ahmed in Arabic (line 1). He does not respond, but a Thai girl, Nok, responds with appreciative laughter (line 3). Yet another child, Abdi, (an Arab boy) notices Fusi's playful action: He code-switches to Swedish, the official language of the classroom, thereby making the play activity transparent to non-speakers of Arabic, and he asks Fusi to let him sit in her chair (line 4). With her greeting 'hej hej' and laughter (line 5), Nok again acknowledges the play frame invoked by Fusi.

While Fusi's choice of Arabic indicates that she adjusts to Ahmed's native language, her Arabic may be doing other interactional work as well. At the time, (as documented in recordings) Fusi did not use the Swedish word 'jag' ('I'). Thus, her choice of 'ana' ('I' in Arabic) provides her with linguistic means to successfully indicate this play activity: By taking Vera's place, Fusi appropriates the teacher's identity. 
Several issues are important to note with reference to Fusi's self-selections during the first period. They were based on fairly predictable summons sequences during individual work on task. However, during such activities, all the children were involved in separate lines of action and calling for the teacher about their work was usually not adjusted to any joint conversational activity. Moreover, Fusi's reliance on the visual mode as a resource for meaning making had implications for the design and timing of her self-selections. For instance, one of her ways of securing the teacher's orientation was to move towards the teacher, or to approach the teacher when she was in her physical proximity. Consequently, Fusi primarily initiated dyadic talk rather than joining into rapid multiparty exchanges.

\section{The second period}

During the second period, that is, in the middle of the year, Fusi had become much more visible in the classroom and on the playground. She volunteered a great deal during individual work on task and tried to position herself as a competent student by claiming that she had done 'all' the exercises, thereby engaging in a popular practice among the children, namely, comparing academic achievements. Fusi used Arabic a great deal, and she apparently attempted to become a part of the group of Arabic children, albeit without success. The children usually treated her as a tag-along and a nuisance, assigning her the least desirable positions in their play activities. Sometimes, they even ridiculed and teased her.

During individual work on task, Fusi frequently talked at a high volume, almost screaming, and her contributions were recurrently marked as unmitigated disagreements, which often resulted in conflicts with the teachers or with the other children. When calling for a teacher, she used loud 
and 'brusque' talk, in an assertive intonation, and repeatedly left her desk without permission. Such moves were accepted when she was still a newcomer (cf., Ex 1). During the second period, however, such actions were usually negatively sanctioned. ${ }^{5}$

Fusi's vocabulary covered a limited although growing range of semantic domains, including glosses for participating in recurrent basic interactional activities ('Jag klar', 'jag klar alla', 'kom'; 'I done', 'I done all', 'come'), polyfunctional words, simple adverbials and deictics. Yet her vocabulary still lacked inflectional morphology: her verb forms primarily involved infinitives and imperatives, such as 'nej skriv!'; 'här skriv!'; 'no write!' and 'here write!', probably modelled on the teacher's directives in classroom management talk (on classroom recyclings, see also Cekaite \& Aronsson, 2004; 2005). These linguistic resources (imperatives) rendered her talk (with the teachers or her classmates) assertive and oppositional. Meaning making was heavily dependent on the teacher's scaffolding in terms of turn-expansions and collaborative cross-turn propositions (Ochs \& Schieffelin, 1983), and when participating in dyadic exchanges with the teacher, Fusi frequently relied on partial repetitions of the teacher's utterances.

\section{Planned discourse in teacher-fronted activities}

Fusi still rarely attempted to join in on rapid multiparty conversations, and she largely relied on turns allocated to her. Primarily, she volunteered during teacher-fronted examinations of language drills, homework assignments and children's rhymes. Such routines constituted conventionalized topics that Fusi could linguistically deal with at the time (cf., Pallotti, 2001). She continuously invested in doing homework, learning songs and rhymes, and then used public recitations of such knowledge as a way of gaining participation in classroom interactions. In the 
following episode, the teacher's aid, Fare, asks the class to name the current season. Just before, they had identified the current month and weekday.

Ex. 3. Teacher's aid FARE, the girls Layla, Fusi and the boys Hiwa, Sawan, Abdi, Miran.

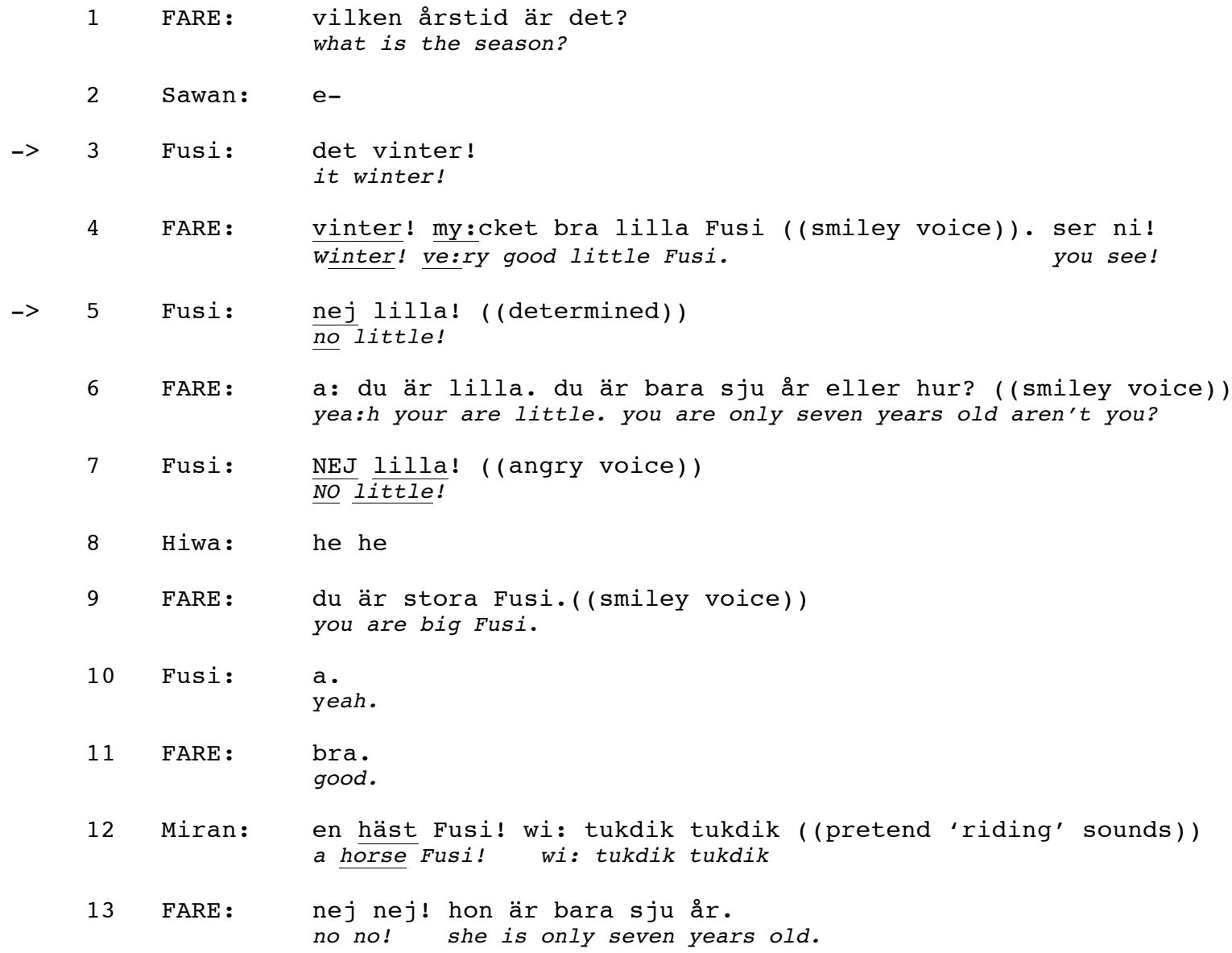

In line 3, Fusi volunteers a correct answer to the teacher's question. She thus interrupts Sawan, who has already started to answer the question (lines 2 and 3). The ethnographic field notes suggest that her self-selection can be characterized as an instance of 'planned language' (Ochs, 1983) in the classroom, such as pre-patterned sequences of months, weekdays and children's songs. 
In response to the teacher's positive evaluation (line 4, 'very good little Fusi'), Fusi formulates a disagreement, including a repetition of his endearment 'no little' (lines 5; 7). The teacher acknowledges her positioning as a 'big' girl in the classroom hierarchy (line 9), but Fusi is teased by Miran (line 12).

Here we can see that opposition and disagreement imply control of conversational space, in that 'Nej lilla' ('No little') is not only responsive to the previous action, but also creates sequential expectations for a subsequent action, clearly inviting a response to her opposition (e.g., Goodwin, 1983). Thereby Fusi prolongs her participation in classroom talk, holding the floor across several turns.

Fusi also tried to join spontaneously evolving multiparty classroom talk. However, producing linguistically novel contributions in a fraction of a second was (still) difficult for her. Instead, she primarily relied on interactional routines in the classroom.

In the following episode (Ex. 4), the teacher, Vera, is about to begin giving whole-group instructions about the classroom aquarium.

Ex. 4 - Teacher VERA, Kurdish language teacher SOUZAN, the girls Layla, Fusi, Nok, Rana and the boys Hiwa, Sawan, Abdi, Miran.

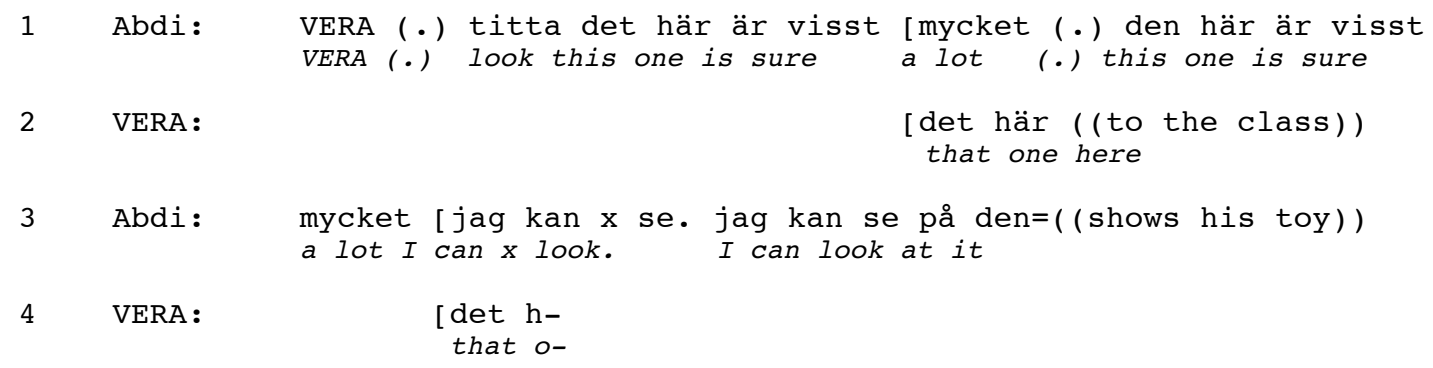




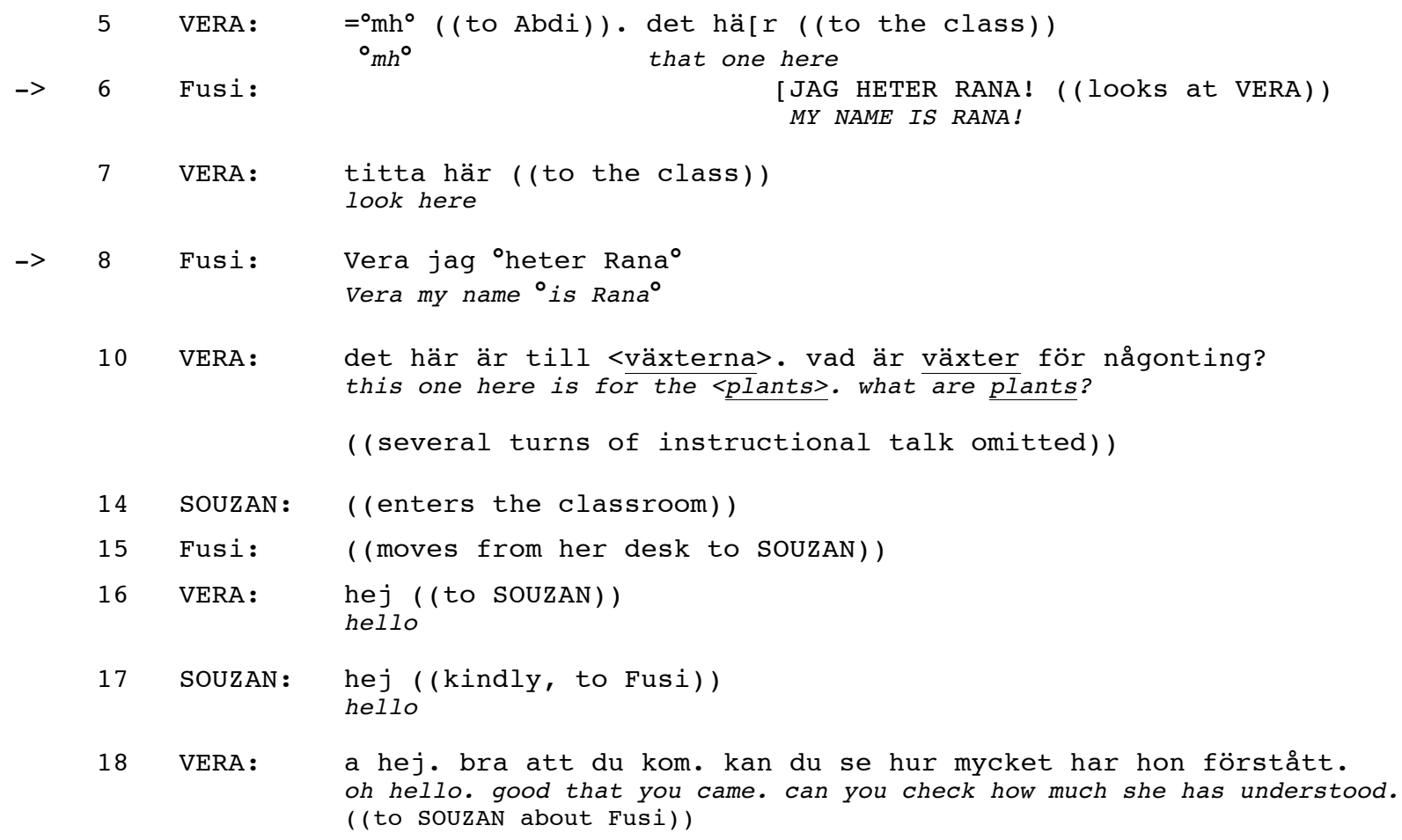

Fusi's announcement overlaps the teacher's instructions to the class (line 6). The timing of her self-selection reveals that Fusi does not quite follow the overall drift of the teacher's previous talk, namely the teacher's repeated attempts to launch instructions (overlapping Abdi's story about his magnifying glass) (lines 2 and 4). Instead, Fusi ties to Abdi's off-task contribution and presents a markedly loud play-invitation, 'jag heter Rana' to the teacher (she is seated in Rana's place). Yet there is no uptake from the teacher, who continues her instructional talk (line 7).

Fusi thus makes another attempt to elicit a playful dialogue with the teacher (line 8). Her selfselection demonstrates her orientation towards possible points of entry into the talk. Generally, the teacher's instructions were conducted at a slow pace and with pausing. Fusi's initiative is suited to fill a conversationally empty slot, a turn following the teacher's instructional talk, involving a sequential position available for the children's activity-relevant self-selections. However, Fusi's play invitations constitute a digression from the main classroom activity and are 
not acknowledged by the teacher. Moreover, the teacher apparently doubts Fusi's Swedish knowledge (whether Fusi has understood any of her previous talk), which may be seen when, some turns later, she asks the Kurdish teacher to check what Fusi has understood (line 18).

As can be seen, this episode is a type of 'identity play' (e.g., Ex.2, the first period) that has become a routinized interactional genre. Compared with Fusi's similar play invitation in Arabic at the outset of the year (Ex.2), Fusi's initiatives (Ex. 4) demonstrate her emerging language skills in that she can now perform the formula in Swedish. However, such routinized contributions still covered a rather limited range of conversational topics, and Fusi's selfselections were often ignored or judged as irrelevant, or disruptive of the ongoing classroom activity.

\section{Aggravated turns of disagreement}

In the following, we will explore Fusi's period II self-selections, shaped as aggravated turns of disagreement. As pointed out earlier, managing the interactional organization of the classroom in order to select an appropriate conversational slot was a key condition for participation in wholegroup discourse. Vocabulary training practices that involved the teacher's reading of picture books and journals allowed for children's spontaneous, at times elaborate contributions located in the turn, following the teacher's production of labels or pictures. ${ }^{6}$ In Ex. 5, the teacher begins by producing a labelling: 'hundvalpen' ('the puppy') demonstrating a picture of a puppy and its reflection in a puddle of water.

Ex. 5. Teacher VERA, the girls Layla, Fusi, Nok, Rana, and the boys Hiwa, Sawan, Abdi, Miran.

1 VERA : $\quad \begin{aligned} & \text { <hundvalpen> } \\ & \text { <the puppy }\end{aligned}$ 


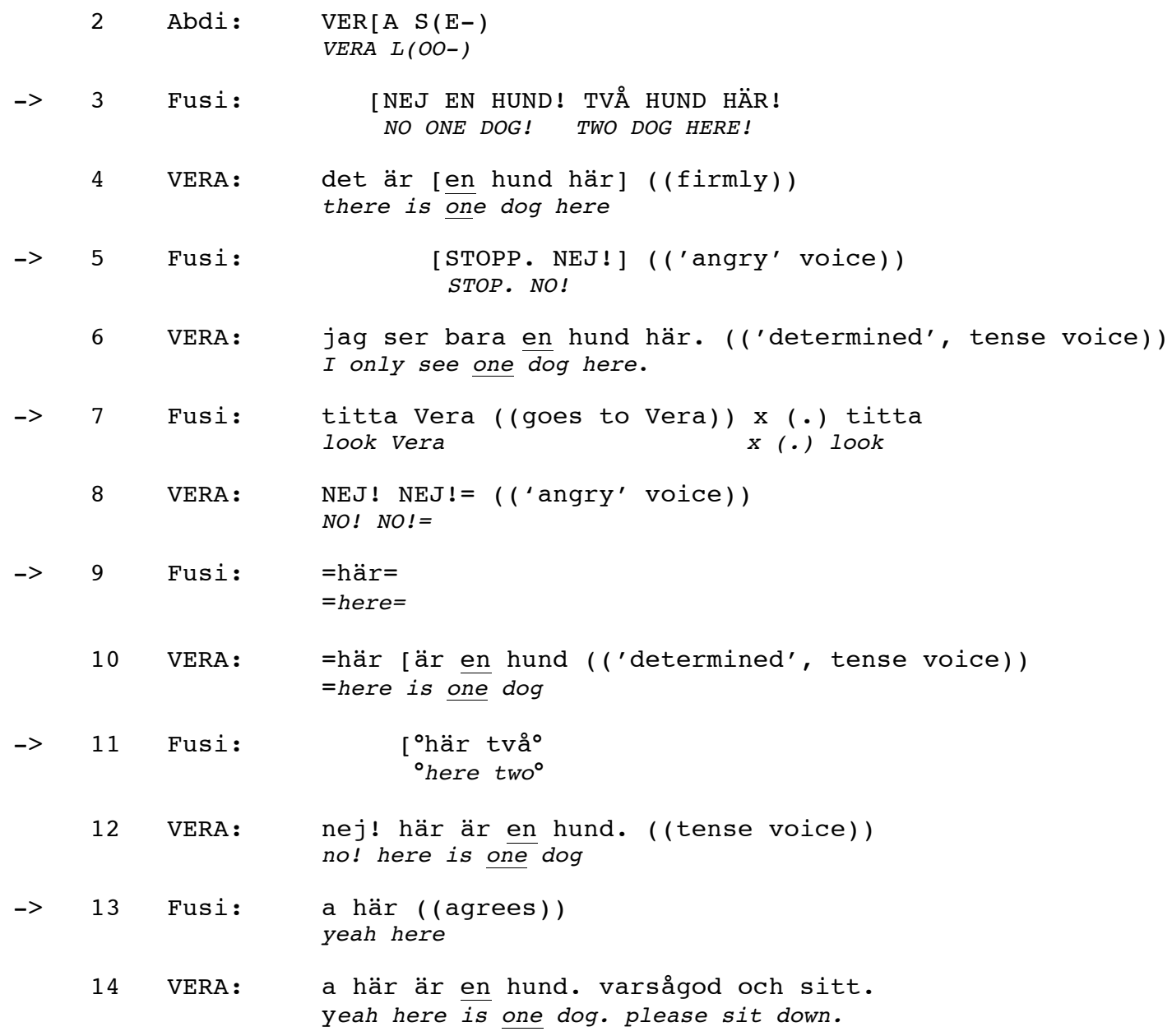

Notice, that Abdi and Fusi both try to fill the sequential slot for self-selection available after the teacher's production of the label (lines 2 and 3). Abdi's turn is overrun by Fusi, who speaks at a markedly high volume, apparently treating this situation as a turn-taking problem in need of repair (French \& Local, 1983). When Abdi cuts short what he is saying, Fusi continues in an almost screaming voice.

Fusi's turn 'No one dog. Two dog' is designed as a disagreement with the teacher's labelling (line 3). A conventionalized way of producing disagreement, a 'dispreferred' action, in adult mundane conversations is to delay disagreement and to first account for the disagreement (Pomerantz, 1984). The production format of Fusi's turn: a turn-initial polarity marker ' $N o$ ' together with the 
immediately following correction ('two $d o g$ '), challenges the teacher's labelling of the picture and indexes Fusi's actions as an unmitigated oppositional stance (e.g., Goodwin, 1983), to which the teacher responds with further disagreement (a 'determined' and tense voice, line 6).

Fusi's 'Stop' and contradictory ' $N o$ ' in a screaming 'angry' voice, may be seen as an aggravated restatement of disagreement, designed to interrupt the teacher (a 'turn-competitive incoming' in the middle of the teacher's turn, French \& Local, 1983). Both the teacher and Fusi persist in their competing versions, formulated as aggravated or at least unmitigated disagreements (lines 6-12).

Fusi leaves her desk and approaches the teacher, probably intending to demonstrate her reading of the picture (to provide an account of her identification of two dogs; lines $7 ; 9 ; 11$ ). Fusi's actions display her adequate understanding of the teacher's prior turn, but leaving her desk is not accepted, and Fusi is sanctioned: the teacher responds with yet another outright opposition, aggravated through repetition, high volume as well as angry voice (' $N O N O$ ', line 8). It is only after repeated opposition to her erroneous labelling that Fusi accepts the teacher's correction (line 13).

The linguistic features of Fusi's talk during the second period reveal that she draws on a rather limited repertoire of words, connected by pragmatic principles of discourse organization (cf., Perdue, 2000). For instance, 'nej $+\mathrm{x}$ ', that is, 'no + noun, imperative, adjective, recycled from the previous speaker's turn, was her commonly used nonstandard format deployed to dispute the prior speaker's turns (e.g., Ex. 3). Such direct disagreements, chiefly characterized by the occurrence of 'no', have been documented in adult L2 English as initial types of disagreement 
formats. Yet in adult conversations, various features mitigate disagreement (downgraders 'maybe', qualifiers, playfulness and explanations) (Bardovi-Harlig \& Salsbury, 2004). Children's socialization into conversational participation in formal learning settings involves learning not only what to say, but also how to say it, which register may be used with which addressee and rules of deference (e.g., Snow \& Blum-Kulka, 2002). ${ }^{7}$ Thus, Fusi's failure to get the teacher's positive acknowledgement may result from an interplay of the linguistic and pragmatic features

of her turn production format. Paradoxically though, it may be these very features that secure Fusi's speakership, trading on the teacher's responsibility to correct incorrect classroom contributions. However, there are potential dangers in employing such marked features of disagreement, in that the speaker risks being seen as an unobservant or socially inept student.

\section{THE THIRD PERIOD: participating as a competent community member}

During period III, that is, at the end of the year, Fusi's position in the classroom community had changed radically. The teachers paid attention to Fusi's initiatives and engaged in conversational exchanges with her. Fusi usually did not leave her desk without the teacher's permission, and she did not contradict the teachers as often as she did during the second period. Moreover, Fusi was no longer the object of the peer group's teasing.

Although Fusi was still a speaker of a 'basic variety' (Perdue, 2000), she clearly demonstrated her emergent creative use of the Swedish language. Her lexicon covered broader semantic domains, and she had developed simple tense markings and abandoned polyfunctional verb imperative forms. 
In a variety of ways, she successfully positioned herself as a 'competent' member of the classroom community, by performing actions that were indexical of a 'competent student' identity (Ochs, 1996). She actively demonstrated her academic knowledge, commented on classroom events and displayed other valued competencies, such as literacy skills in Arabic and Swedish (frequently borrowing books from the school library). Fusi had by now abandoned her loud and overly 'assertive' interactional style, and she was treated as an observant and wellorganized student. Although far from all of her numerous self-selections were picked up by the teacher, Fusi was successful in introducing her contributions, and they were recurrently incorporated into subsequent discourse.

\section{Defending a controversial standpoint}

As we have seen in Ex. 5, a self-selection containing a controversial piece of information was likely to elicit the teacher's response. However, knowing how to defend one's standpoint and how to display disagreement seemed to be of crucial importance to securing the teacher's positive acknowledgement.

The following example demonstrates how Fusi successfully self-selects with a new topic. Moreover, she is able to defend her controversial statement. The teacher, Vera, and the children talk about dogs, discussing whether it is objectionable when dogs' tails are cropped.

Ex. 6. Teacher VERA, teacher's aid FARE and the girls Layla, Fusi, Nok, Rana, and the boys Hiwa, Sawan, Abdi, Miran.

\footnotetext{
1 VERA: det gör ju väldigt ont och är otrevligt. it hurts a lot and is unpleasant. 


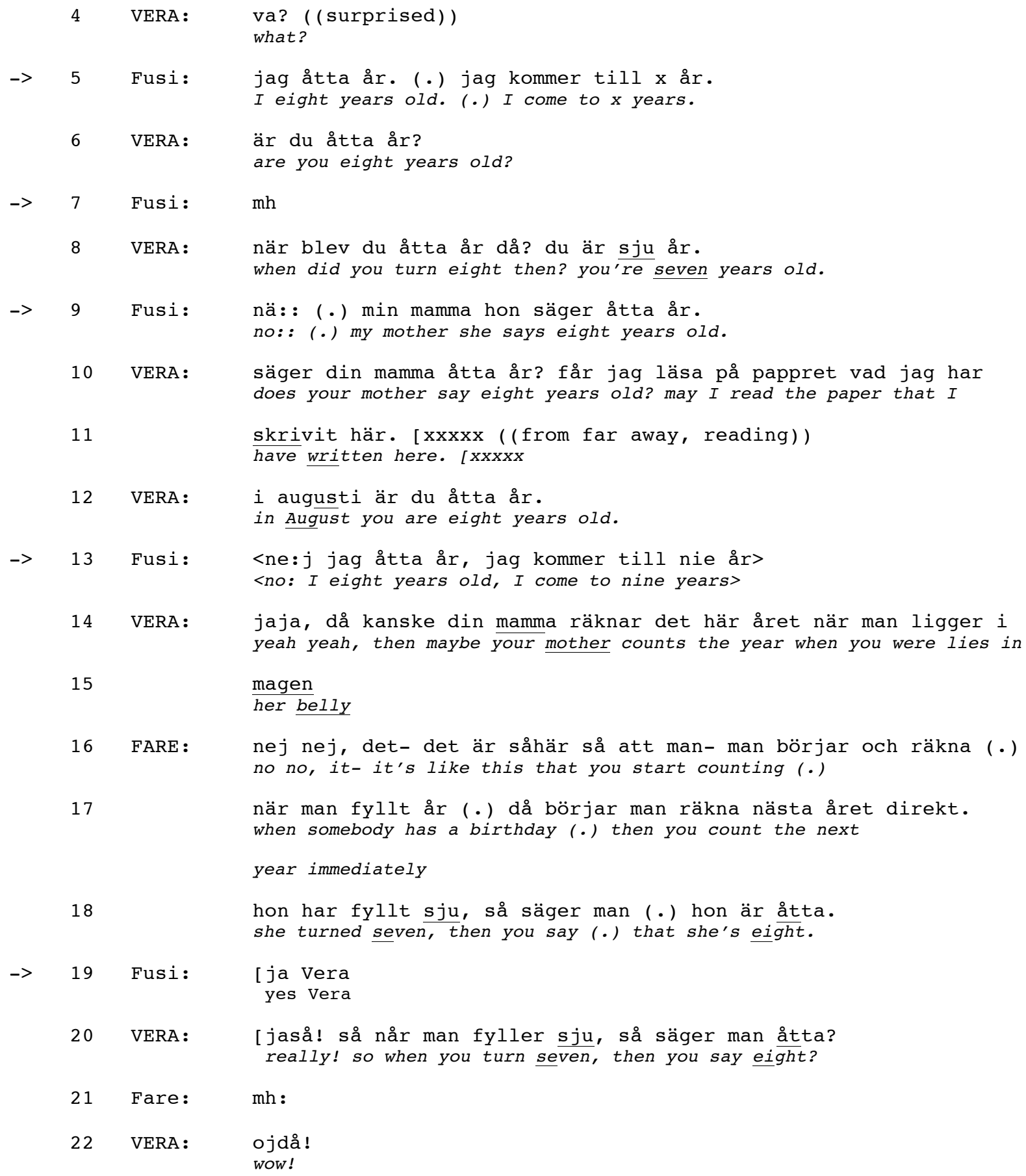

Hiwa and Fusi both self-select in a simultaneous start after the teacher's turn completion (lines 2 and 3), and Fusi wins the turn. Let us look at how Fusi's self-selection is designed (line 3). The statement 'I eight years old' introduces a new topic. Fusi's precision-timed initiative displays her understanding of the on-going development of the current sequence (child-centered free 
conversation) allowing her to take a turn after the teacher's turn-completion. Her statement is probably modelled on self-presentation routines, e.g. 'Jag är x år' ('I'm $x$ years old'), well rehearsed in this classroom. It also involves a controversial announcement: Fusi claims that she is eight years old, while she is, in fact, only seven.

Fusi accompanies her self-selection with an iconic gesture, displaying eight fingers within the teacher's view. While her gesture may be seen as redundant, as the number is also indicated verbally, it not only embellishes her self-selection, but it disambiguates the possible interpretation of her not knowing numbers/age in Swedish (e.g., Goodwin, 2000).

As may be seen from the teacher's clarification request (line 4) issued with a 'surprise' intonation, she immediately abandons the main classroom activity: 'talking about dogs'. Instead, Fusi's age ascription now becomes the official business of the classroom. The teacher corrects Fusi's 'misinformed' contribution (line 8) (cf., Ex. 6). Although Fusi's next turn (line 9) contains a turn-initial opposition marker 'nä:' ('no'), indicating a direct disagreement, it is prosodically neutrally marked and is followed by an explanation that legitimates her initial age description. Thereby, she modulates her disagreement. The teacher does not dismiss Fusi's account. Instead, she moves to the note board to check the information concerning Fusi's age, and once again states that Fusi will turn eight in August (lines 10-12). Fusi's following disagreement (line 13), similar to her disagreement in line 9, contains a turn-initial opposition marker. The teacher then agrees, orienting to Fusi's mother as the authority (lines 14-15).

At this point, Fare, the teacher's aid, explains how age categories work in Kurdistan, and why Fusi's age ascription is, in fact, correct (lines 16-18). Here, Fusi makes another entry into the 
conversation and acknowledges the teacher's aid's explanation (line 19). She does it at an interactionally appropriate place, displaying precision timing in relation to the development of Fare's talk as well as sensitivity to the content of Fare's explanation. After several turns of explanations (lines 20-21), the teacher Vera at last acknowledges her understanding of this specific age system (line 22).

As can be seen in example 5, Fusi's oppositional turns were designed as direct disagreements. Yet due to her emerging interactional skills, namely, the use of relevant lengthy accounts and prosodic cues, she provided an acceptable explanation of her stance and modulated her opposition. As may be seen, there were changes over time in how Fusi expressed disagreement and defended her standpoint, which all had implications for how she was treated as a conversational partner (cf., Ex. 3, Ex. 5).

\section{'First things first': marking the newsworthiness of self-selections}

At times, the children's contributions during picture labelling activities involved rather lengthy narratives concerning their personal experiences, a specific genre of 'exploratory epistemic talk', connecting the students' experiences (e.g., from their homeland) to the pedagogical content of what was being taught (Boyd \& Maloof, 2000). Generally, such self-selections were about to bring responses from the teacher.

In the following, we will explore Fusi's use of interactional resources that enabled her to immediately frame her self-selection as 'exploratory epistemic talk'. When the episode starts, the teacher has shown a picture of a lizard, and several children volunteer related stories from Iraq. 
Ex.7. Teacher VERA, the girls Fusi, Nok, and the boys Hiwa and Sawan.

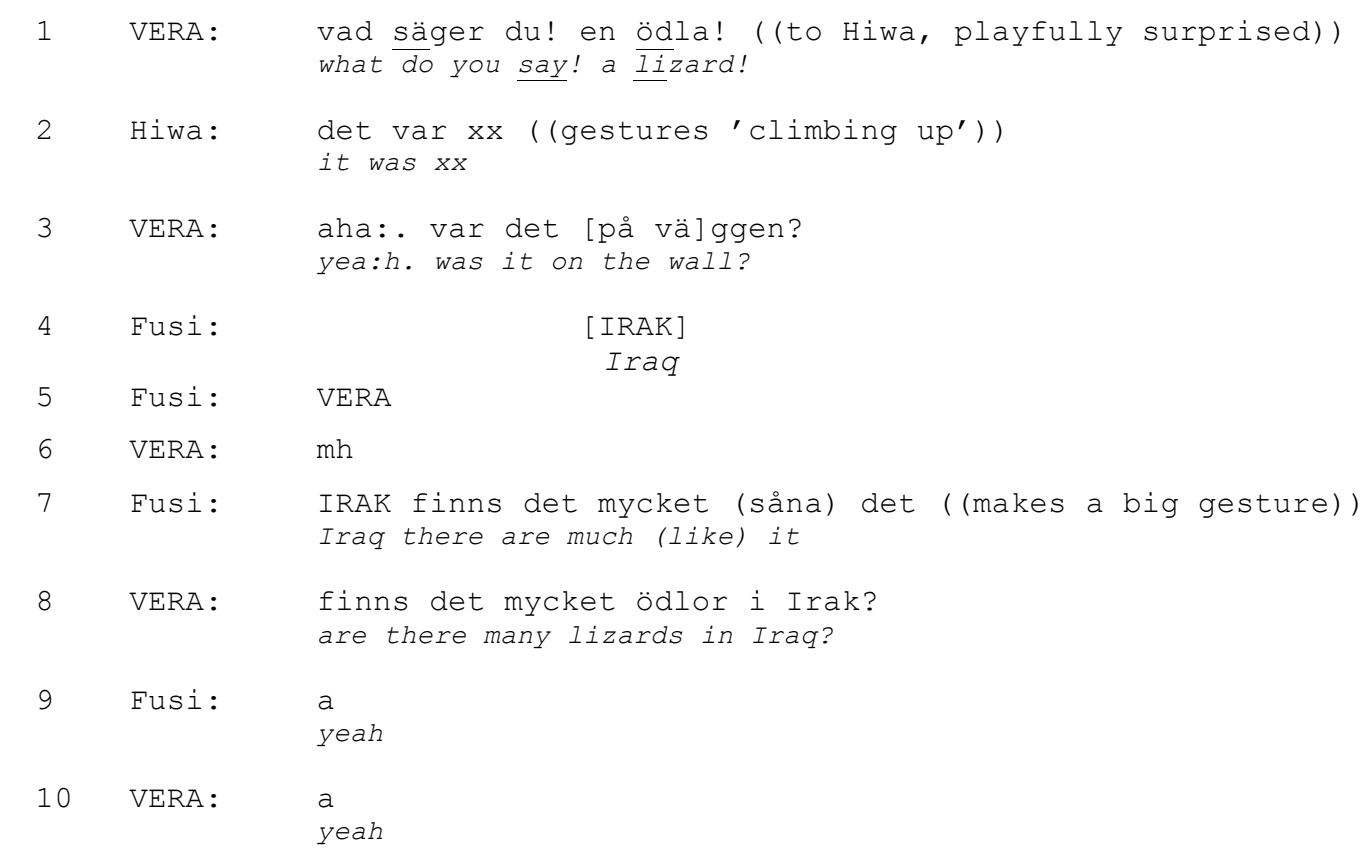

In line 4, Fusi overlaps the teacher's question with a location marker 'Iraq'. Upon finding herself in overlap, Fusi cuts off, waits for the teacher's turn completion and secures her speakership by summoning the teacher. It is noticeable that Fusi's restart begins exactly at the point where her talk is no longer in overlap. Thereby, she avoids simultaneous talk with the teacher. Moreover, by using the turn-initial location marker 'Iraq', she immediately makes a link to the topic of the teacher's and Hiwa's conversation, framing her contribution according to the genre of 'exploratory epistemic' talk. As pointed out by Schegloff, '[t]urns project, from their beginning, aspects of their planned shape and type' (1987, p. 71). 'I Irak' (or Fusi’s ungrammatical 'Irak', line 7) constituted a conventionalized turn-initial phrase in the children's initiatives employed when self-selecting in overlap-sensitive sequential positions and served to indicate the newsworthiness of conversational material. ${ }^{8}$ It is also emphatically marked (raised volume). Thereby, the dislocated element is defined as a thematic focus of the turn in progress. Just before, the teacher had heard several dramatic accounts of the children's experiences in their home 
countries: shooting some dangerous animal in a bathroom or discovering a scary lizard in the living room. Although Fusi's contribution does not involve dramatic elements, she is able to add some new information to the ongoing topic by generalizing previous narratives about lizards in Iraq.

In her request for confirmation, the teacher reformulates Fusi's utterance syntactically and provides a gloss for her generalization 'såna det' (line 8). Thus, at the end of the year, by repeating Fusi's contributions as well informed and relevant, the teacher offers Fusi more rights to participation, thereby co-constructing Fusi as a competent and motivated student (e.g., Cekaite, 2006; Lave \& Wenger, 1991; Young \& Miller, 2004).

\section{'Stealing' a turn}

Interactional participation in the present classroom recurrently involved children's exploitation of turns allocated to other speakers. The following episode exemplifies such thematically coherent, linguistically novel and precision timed contributions to rapidly evolving multiparty talk. This episode (Ex. 8) began when the teacher asked the whole group if they had eaten breakfast. On

numerous occasions, the teacher had pointed out and discussed with the children the importance of breakfast to being alert and receptive at school.

Ex. 8. Teacher VERA, and the girls Layla, Fusi, Nok, Rana and the boys Hiwa, Sawan, Abdi, Miran.

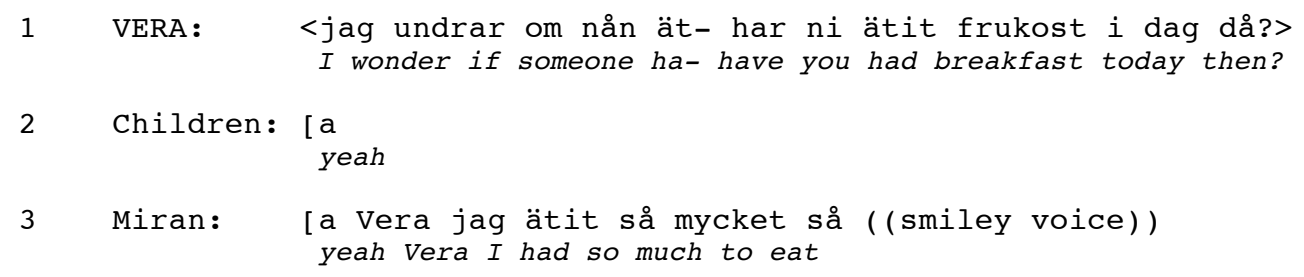




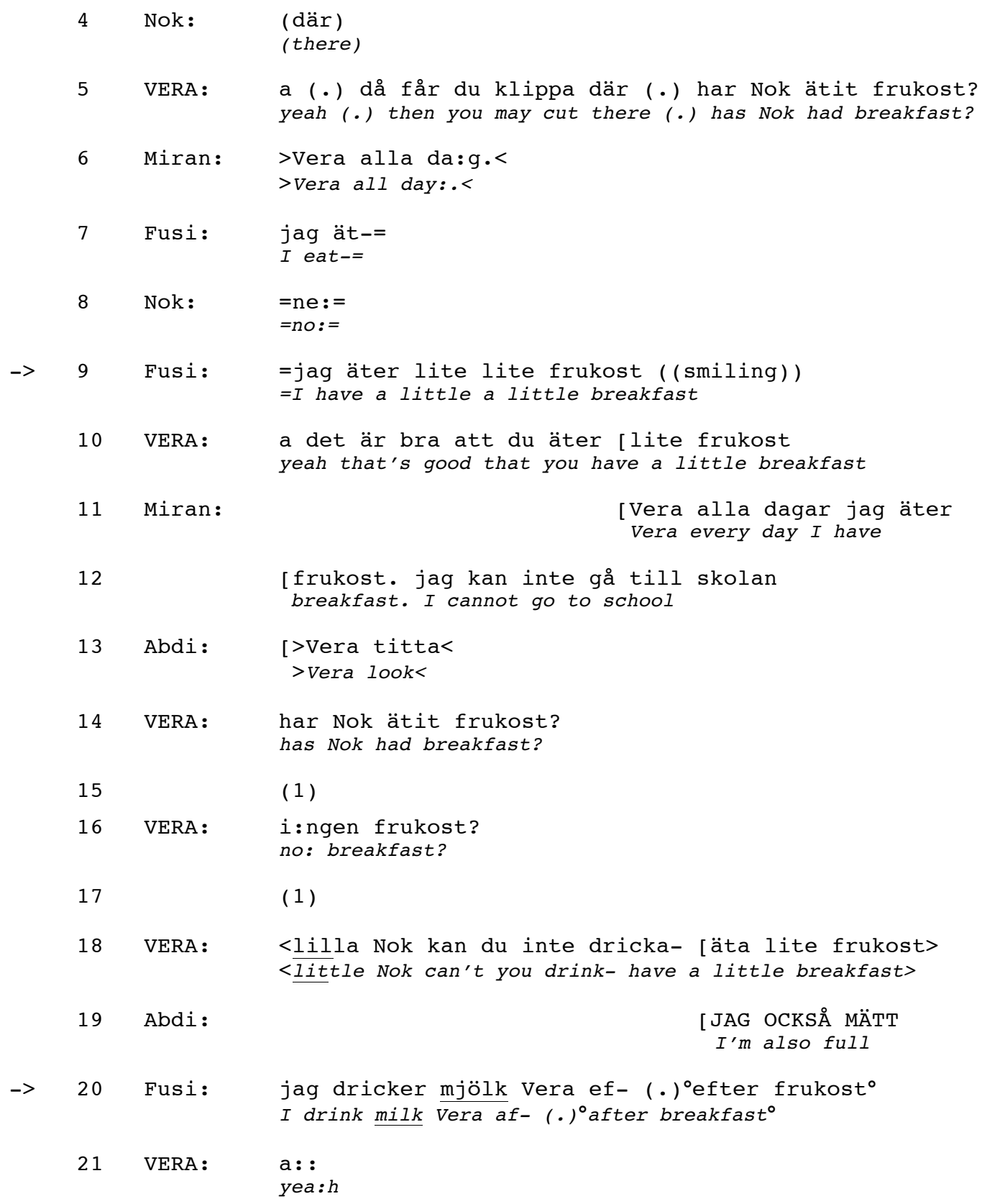

After students' choral responses (Lerner, 1995) the teacher specifically addresses Nok (line 5), but other students appropriate her turn. Here we can see that speaking rights in this particular classroom are relatively free, and several students (Miran and Fusi) immediately self-select, accounting for their breakfast habits. Thus, one way of attaining speakership is to self-select at an empty conversational slot. In cases when the answer of the allocated speaker was not 
forthcoming, as in the present example, the self-selectees' contribution appeared in an empty sequential position.

Let us look closer at how Fusi's self-selections (lines 7-9) are designed. First, they are tied to the spontaneous multiparty talk; her self-selection in line 9 is also more verbally elaborate and syntactically close to target language norms. Fusi self-selects 'in the clear', starting her answer after Miran's turn (which is an intonationally complete turn-construction unit). Second, Fusi produces her utterance with a smiley voice and laughter tokens. Together with linguistic markers of affect, 'little little', (so-called 'quantifiers', Ochs, 1996) she displays the affective stance of a diligent pupil who complies with the approved norms of student identity for the current classroom community (Kyratzis, 2004). Note the teacher's affective affiliation with Fusi (incorporating 'little' into her response, line 10).

When the teacher issues an implicit directive to Nok (line 18), the unaddressed children again seize the opportunity to launch their accounts of breakfast habits (Abdi, line 19; Fusi, 20). Fusi's self-selection is precisely timed to appear at the TRP of the teacher's turn (line 20). Thematically, Fusi elaborates on 'drinking milk after breakfast', that is, another feature of good breakfast habits. It adds a new dimension to Fusi's display of her actions as a competent student.

In the present case, the timing of Fusi's self-selections may be seen to indicate her emerging competencies, in that 'precision timing' involves the speaker's language processing skills (ErvinTripp, 1979), including pragmatic, syntactic and prosodic analysis of ongoing talk (Ford \& Thompson, 1996). Her external appropriation of 'dricka' ('drink') (Pallotti, 2001) and her focusing of her contribution on this new theme demonstrate Fusi's growing language production 
skills, which allow her to produce a novel and relevant contribution in a split of a second. Fusi's present deployment of linguistic and paralinguistic devices for marking an 'appropriate' affective stance (Ochs, 1996) are also important in eliciting the teacher's positive acknowledgement.

\section{CONCLUDING DISCUSSION}

The present study demonstrates how an L2 novice was socialized into competent ways of participating in teacher-fronted classroom talk during her first school year. The analyses have focused on how teacher-led multiparty communicative practices constitute a distinct interactional setting that, in specific ways, structures L2 novice's opportunities for conversational participation, thereby providing affordances for acquiring conversational and linguistic skills. In prior longitudinal work on children's L2 socialization in classrooms, novices' language acquisition has been seen as a result of children's participation in classroom events, shaped by teacher's interactional organization of learning practices and the micropolitics of classroom interactions. In the present study, detailed analyses of how the novice's self-selections were negotiated, accepted or rejected revealed the intricate ways in which participation in classroom conversational activities was highly dependent on the L2 learner's mastery of the local institutional norms of interaction.

During the year, Fusi's loud and noisy 'personality' markedly shifted, from an 'incompetent', 'unobservant' and 'immature 7 year-old' during the second period to a 'skilful' and 'mature' language learner at the end of the year. Instead of offering an individual psychological interpretation, I will focus on Fusi's learner identity as evidenced by her linguistic and turn- 
taking choices, suggesting that they were consequential to Fusi's participation in classroom interactions. These resources worked together to help her gain membership in the classroom community.

At the beginning of the year, that is, during the first period, Fusi was mostly silent and only participated very marginally in classroom interactions. Yet she was able to comply with the social expectations for her limited interactional performance, in that she rarely interrupted or disturbed other speakers. She was thus seen as an 'unproblematic' child.

During the second period, Fusi's Swedish language skills were emerging, and she was eager to participate in classroom activities. However, she repeatedly employed inappropriate production formats, failing to locate her initiatives at appropriate sequential slots, or designing her contributions as aggravated direct disagreements. On occasions of simultaneous talk with the teacher, she attempted to 'win' the turn by markedly raising the volume of her talking (e.g., Ex. 6). Hence, while Fusi, as 'good language learner' (O’Malley \& Chamot, 1990) was seeking out talk opportunities in the classroom, due to breaches of the interactional norms for classroom discourse, her actions often resulted in reprimands, disciplining or peer group teasing (for a problematization of the 'good language learner' as an individual concept, see Norton, 2000). The teacher's non-responses or disciplining moves (as well as peer self-selections) provided implicit socialization into what was the socially approved or, on the contrary, inappropriate interactional design of self-selections (e.g., Lave \& Wenger, 1991).

During the third period, that is, at the end of the year, she mastered a more elaborate L2 (Swedish) repertoire and developed interactional skills that allowed her to participate in 
spontaneously evolving whole-group conversational activities, which in their turn shaped interactional learning affordances. Her timely self-selections involved more than anticipating turn completion points, she was able to self-select at the 'right' moment, thereby displaying her knowledge of the sequential organization of the classroom activity. ${ }^{9}$ Through everyday participation in classroom activities, Fusi had appropriated the competitive, albeit relevant manner of how such initiatives were to be designed (indexing her initiatives with 'appropriate' affective stances, shaping her self-selections in a way that immediately indicated the newsworthiness of her contributions). In cases of simultaneous talk with the teacher, she would 'cut off' her contributions (Ex. 7; Ex. 10). Hence, at the end of the year, Fusi ultimately performed as a socially competent actor who, at least in part, had acquired the capacity to selfselect and to participate in whole-group activities in accordance with the cultural expectations of the immersion classroom (e.g., Bruner, 1996).

This trajectory, from a silent and compliant child (period I), to a loud and noisy student (period II) and finally to a 'skilful student' (period III), demonstrates that learning and participation cannot be seen as a unilinear development towards full participation, or as a unidirectional development of one specific learner identity. Over time, one and the same L2 learner can position herself very differently within the classroom community, partly depending on her interactional skills. Hence, rather than studying an L2 novice's single 'learner identity' as a fixed entity, dissociated from his or her participation in classroom activities, we need more longitudinal work on the social dimension of participation and L2 learning in multiparty classroom settings. Instead of a unilinear 'development', we may be able find different trajectories, linked to distinct interactional language learning affordances over time. 


\section{Acknowledgements}

The earlier version of this article was presented at the 14th World Congress of Applied Linguistics (AILA), July 24-29, 2005 in Madison, Wisconsin. Thanks are due to Karin Aronsson, Ann-Carita Evaldsson, Polly Björk-Willén, Jakob Cromdal, Ben Rampton, Sally Sieloff Magnan, and three anonymous reviewers, for their helpful comments on an earlier draft. Financial support from the Swedish Research Council is gratefully acknowledged.

\section{Notes:}

${ }^{1}$ On children's L1 'pragmatic socialization' including mastery of 'turn-taking rules, rules of politeness, modes of story-telling', topic introduction and maintenance (Blum-Kulka, 1997) in family and school settings (see Blum-Kulka, 1997; Phillips, 1972).

${ }^{2}$ Adult L2 learning as related to the interactional organization of learning activities in formal settings has been the focus of several CA-based studies (Markee, 2000; Mori, 2002). In a study of Japanese adult learners' of English, Carroll (2000) demonstrated how L2 novices were able to 'precision time' their turns, skilfully identifying transition-relevant places during ongoing talk. These findings point out that smooth accomplishment of speaker change is illuminative of learners' 'discourse-pragmatic' abilities, or their knowledge of the turn-taking operating in a particular speech exchange system (Kasper \& Ross, 2002, p. 209). Changing patterns of participation in a formal learning activity ('writing session') were conceptualized in terms of the adult learner's increasing interactional skills of turn-taking management (Young \& Miller, 2004).

${ }^{3}$ For a longitudinal microanalytic study of adult L2 interactional competence (development of expressions of alignment in Japanese), see Ohta (1999). 
${ }^{4}$ Self-selections are typical of teacher-fronted exchanges in child-centred educational settings in Sweden, and are viewed as methods by which active students who take responsibility for their own learning are socialized.

${ }^{5}$ In an informal interview during this period, the teacher characterized Fusi as an immature 7 year-old'.

${ }^{6}$ Usually, such labelling procedures not only provided a correct lexical and phonological model, but also required that the participants practise or display their linguistic skills: lexico-semantic, phonologic, word finding, and narrative abilities.

${ }^{7}$ Fusi's present way of highlighting disagreement bears resemblance to procedures found among children in various peer group interactions, indicating that in some children peer group conflicts 'can provide a primary way of dealing with coparticipants in interaction' (Goodwin, 1983, p. 658; Evaldsson, 2004; Kyratzis, 2004).

${ }^{8}$ Thereby, the competitive multiparty conversations shaped the novice's L2 learning in that it provided affordances for syntactic analysis of the turn elements, for instance, what elements may be foregrounded.

${ }^{9}$ As indicated in the analyses, Fusi was able to project the TRP in simple dyadic exchanges from early on. Her limited participation in whole-group activities during the second period may be indicative of Fusi's difficulties in locating TRP during an ongoing multiparty conversation.

\section{Transcription key}

: $\quad$ : prolonged syllable

[ ] : demarcates overlapping utterances

(.) : micropause, i.e. shorter than (0.5)

(2) : numbers in single parenthesis represent pauses in seconds

YES : relatively high amplitude 


$$
\begin{array}{ll}
\mathrm{x} & \text { : inaudible word } \\
(\mathrm{xx}) & : \text { unsure transcription } \\
\text { what } & : \text { word in English } \\
\text { jala } & : \text { word in Arabic } \\
\circ \quad \circ & : \text { denotes speech in low volume } \\
(()) & : \text { further comments of the transcriber } \\
>< & : \text { quicker pace than surrounding talk } \\
<> & : \text { slower pace than surrounding talk } \\
? & : \text { denotes rising intonation } \\
\cdot & : \text { indicates falling terminal intonation } \\
= & : \text { denotes latching between utterances } \\
\text { Fare } & : \text { sounds marked by emphatic stress are underlined } \\
\text { he } & : \text { indicates laughter }
\end{array}
$$

\section{REFERENCES}

Bardovi-Harlig, K., \& Salsbury, T. (2004). The organization of turns in the disagreements of L2 learners: A longitudinal perspective. In D. Boxer \& A. D. Cohen (Eds.), Studying speaking to inform second language learning (pp. 68-87). Clevedon: Multilingual Matters.

Bayley, R., \& Schecter, S. R. (Eds.). (2003). Language socialization in bilingual and multilingual societies. Clevedon: Multilingual Matters.

Bialystok, E. (1993). Symbolic representation and attentional control in pragmatic competence. In G. Kasper \& S. Blum-Kulka (Eds.), Interlanguage pragmatics (pp. 43-59). New York: Oxford University Press.

Blum-Kulka, S. (1997). Dinner talk. Mahwah, NJ: Lawrence Erlbaum.

Boyd, M., \& Maloof, V. M. (2000). How teachers can build on student-proposed intertextual links to facilitate student talk in the ESL classroom. In J. K. Hall \& L. S. Verplaetse (Eds.), 
Second and foreign language learning through classroom interaction (pp. 163-182). Mahwah, NJ: Lawrence Erlbaum.

Bruner, J. (1996). The culture of education. Cambridge, MA: Harvard University Press.

Cekaite, A. (2006). Getting started: Children's participation and language learning in an L2

classroom. Unpublished doctoral dissertation. Linköping Studies in Arts and Science 350:

Linköping University, Sweden.

Carroll, D. (2000). Precision timing in novice-to-novice L2 conversations. Issues in Applied

Linguistics, 11, 67-110.

Cekaite, A., \& Aronsson, K. (2004). Repetition and joking in children's second language

conversations: playful recyclings in an immersion classroom. Discourse Studies, 6, 373-392.

Cekaite, A., \& Aronsson, K. (2005). Language play, a collaborative resource in children's L2 learning. Applied Linguistics, 26, 169-191.

Duff, P. A. (1995). An ethnography of communication in immersion classrooms in Hungary. TESOL Quarterly, 29, 505-537.

Ellis, R. (1992). Learning to communicate in the classroom: A study of two learners' requests. Studies in Second Language Acquisition, 14, 1-23.

Ervin-Tripp, S. (1979). Children's verbal turn-taking. In E. Ochs \& B. Schieffelin (Eds.), Developmental pragmatics (pp. 391-414). New York: Academic Press.

Evaldsson, A-C. (2004). Shifting moral stances: morality and gender in same-sex and cross-sex game interaction. Research on Language and Social Interaction, 37, 331-363.

French, P., \& Local, J. (1983). Turn competitive incomings. Journal of Pragmatics, 7, 17-38. 
Ford, C., \& Thompson, S. (1996). Interactional units in conversation: Syntactic, intonational, and pragmatic resources for the management of turn. In E. Ochs, E. A. Schegloff \& S. Thompson (Eds.), Interaction and grammar (pp. 134-184). Cambridge: Cambridge University Press.

Garrett, P., \& Baquedano-Lopez, P. (2002). Language socialization: Reproduction and continuity, transformation and change. Annual Review of Anthropology, 31, 339-61.

Goffman, E. (1963). Behavior in public places. London: The Free Press of Glencoe.

Goffman, E. (1981). Forms of talk. Oxford: Blackwell.

Goodwin, M. H. (1983). Aggravated correction and disagreement in children's conversations. Journal of Pragmatics, 7, 657-77.

Goodwin, C. (2000). Action and embodiment within situated human interaction. Journal of Pragmatics, 32, 1489-1522.

Hall, J. K. (1998). Differential teacher attention to student utterances: The construction of different opportunities for learning in the IRF. Linguistics and Education, 9, 287-311.

Hall, J. K. (1999). A prosaics of interaction. The development of interactional competence in another language. In E. Hinkel (Ed.), Culture in second language teaching and learning (pp. 137151). Cambridge: Cambridge University Press.

Hall, J. K. (2004). "Practising speaking” in Spanish: Lessons from a high school foreign language classroom. In D. Boxer \& A. D. Cohen (Eds.), Studying speaking to inform second language learning (pp. 68-87). Clevedon: Multilingual Matters.

Hawkins, M. (2005). Becoming a student: Identity work and academic illiteracies in early schooling. TESOL Quarterly, 39, 59-82.

He, A. W. (2000). The grammatical and interactional organization of teacher's directives: Implications for socialization of Chinese American children. Linguistics and Education, 11, 119140. 
He, A. W. (2003). Novices and their speech roles in Chinese heritage language classes. In R.

Bayley \& S. Schecter (Eds.), Language socialization in bilingual and multilingual societies (pp. 128-146). Clevedon: Multilingual Matters.

Heritage, J. (1984). Garfinkel and ethnometodology. Polity Press.

Hymes, D. (1972). On communicative competence. In J. B. Pride \& J. Holmes (Eds.), Sociolinguistics (pp. 269-93). Harmondsworth: Penguin.

Kanagy, R. (1999). Interactional routines as a mechanism for L2 acquisition and socialization in an immersion context. Journal of Pragmatics, 31, 1467-1492.

Kasper, G., \& Rose, K. R. (2002). Pragmatic development in a second language. A supplement to Language Learning. Volume 52, supplement 1.

Kyratzis, A. (2004). Talk and interaction among children and the co-construction of peer groups and peer culture. Annual Review of Anthropology, 33, 625-649.

Lave, J. \& Wenger, E. (1991). Situated learning: Legitimate peripheral participation.

Cambridge: Cambridge University Press.

Lerner, G. (1995). Turn design and the participation in instructional activities. Discourse

Processes, 19, 111-131.

Markee, N. (2000). Conversation analysis. Mahwah, NJ: Lawrence Erlbaum.

Mehan, H. (1979). Learning lessons: The social organization of classroom behavior. Cambridge, MA: Harvard University Press.

Mondada, L., \& Pekarek Doehler, S. (2004). Second language acquisition as situated practice:

Task accomplishment in the French second language classroom. Modern Language Journal, 88, $501-518$

Mori, J. (2002). Task design, plan, and development of talk-in-interaction: an analysis of a small group activity in a Japanese language classroom. Applied Linguistics, 23, 323-347. 
Morita, N. (2000). Discourse socialization through oral classroom activities in a TESL graduate program. TESOL Quarterly, 34, 279-310.

Norton, B. (2000). Identity and language learning. Harlow, UK: Pearson.

Ochs, E. (1983). Planned and unplanned discourse. In E. Ochs \& B. Schieffelin, Acquiring conversational competence (pp. 129-157). London: Routledge \& Kegan Paul.

Ochs, E. (1996). Linguistic resources for socializing humanity. In J. Gumperz \& S. Levinson (Eds.), Rethinking linguistic relativity (pp. 407-437). New York: Cambridge University Press. Ochs, E., \& Schieffelin, B. (1983). Topic as discourse notion: A study of topic in the conversations of children and adults. In E. Ochs \& B. Schieffelin (Eds.), Acquiring conversational competence (pp. 66-113). London: Routledge \& Kegan Paul.

Ohta, A. S. (1999). Interactional routines and the socialization of interactional style in adult learners of Japanese. Journal of Pragmatics, 31, 1493-1512.

O’Malley, J., \& Chamot, A. (1990). Learning strategies in second language acquisition. Cambridge: Cambridge University Press.

Pallotti, G. (2001). External appropriations as a strategy for participating in intercultural multiparty conversations. In A. Di Luzio, S. Gunthner, \& F. Orletti (Eds.), Culture in communication (pp. 295-334). Amsterdam: Benjamins.

Perdue, C. (Ed.). (2000). The structure of learner varieties. Studies in Second Language Acquisition, 22.

Peräkylä, A. (1997). Reliability and validity in research based on transcripts. In D. Silverman (Ed.), Qualitative research (pp. 201-220). London: Sage.

Peters, A. M., \& Boggs, S. T. (1986). Interactional routines as cultural influences upon language acquisition. In B. Schieffelin \& E. Ochs (Eds.), Language socialization across cultures (pp. 8096). New York: Cambridge University Press. 
Philips, S. (1970). Participant structures and communicative competence: Warm Springs children in community and classroom. In J. E. Alatis (Ed.), Bilingualism and language contact. Washington D.C.: Georgetown University Press.

Platt, E., \& Troudi, S. (1997). Mary and her teachers: A Grebo-speaking child's place in the mainstream classroom. Modern Language Journal, 81, 28-49.

Pomerantz, A. (1984). Agreeing and disagreeing with assessments: some features of preferred/dispreferred turn shapes. In J. Atkinson \& J. Heritage (Eds.), Structures of social action (pp. 79-112). Cambridge: Cambridge University Press.

Rogoff, B. (2003). The cultural nature of human development. Oxford, NY: Oxford University Press.

Sacks, H., Schegloff, E. A., \& Jefferson, G. (1974). A simplest systematics for the organization of turn-taking for conversation. Language, 50, 696-735.

Schegloff, E. A. (1987). Recycled turn beginnings: A precise repair mechanism in conversation's turn-taking organisation. In G. Button \& A. Lee (Eds.), Talk and social organization (pp. 70-85). Clevedon: Multilingual matters.

Schegloff, E. A., Koshik, I., Jacoby, S., \& Olsher, D. (2002). Conversation analysis and applied linguistics. Annual Review of Applied Linguistics, 22, 3-31.

Schieffelin, B., \& Ochs, E. (1996). The microgenesis of competence: methodology in language socialization. In D. J. Slobin, Gerhardt, A. Kyratzis \& J. Guo (Eds.), Social interaction, social context, and language (pp. 251-263). Mahwah, NJ: Lawrence Erlbaum.

Snow, C. E., \& Blum-Kulka, S. (2002). From home to school: School-age children talking to adults. In S. Blum-Kulka \& C. E. Snow (Eds.), Talking to adults: The contribution of multiparty discourse to language acquisition (pp. 327-341). Mahwah, NJ: Lawrence Erlbaum. 
Toohey, K. (1998). ‘Breaking them up; taking them away': ESL students in grade one. TESOL Quarterly, 32, 61-84.

Tsai, M., \& Garcia, G. E. (2000). Who's the boss. How communicative competence is defined in a multilingual preschool classroom. Anthropology \& Education Quarterly, 31, 230-252.

Vygotskij, L. (1978). Mind in society. Cambridge, MA: Harvard University Press.

Walters, J. (1980). Grammar, meaning, and sociological appropriateness in second language acquisition. Canadian Journal of Psychology - Revue Canadienne de Psychologie, 34, 337-345.

Watson-Gegeo, K. A. (2004). Mind, language and epistemology: Toward a language socialization paradigm for SLA. Modern Language Journal, 88, 331-350.

Willett, J. (1995) Becoming first graders in an L2: An ethnographic study of L2 socialization. TESOL Quarterly, 29, 473-503.

Young, R., \& Miller, E. (2004). Learning as changing participation: Discourse roles in ESL writing conferences. Modern Language Journal, 88, 519-535. 